Kansas State University Libraries

New Prairie Press

\title{
SIMULATION AND RESPONSE SURFACE METHODOLOGY TO OPTIMIZE WINTER WHEAT RESPONSE TO GLOBAL CLIMATE
} CHANGE

P. Dhungana

K. M. Eskridge

A. Weiss

P. S. Baenziger

See next page for additional authors

Follow this and additional works at: https://newprairiepress.org/agstatconference

Part of the Agriculture Commons, and the Applied Statistics Commons

\section{(c) (1) $\Theta(9$}

This work is licensed under a Creative Commons Attribution-Noncommercial-No Derivative Works 4.0 License.

\section{Recommended Citation}

Dhungana, P.; Eskridge, K. M.; Weiss, A.; and Baenziger, P. S. (2002). "SIMULATION AND RESPONSE SURFACE METHODOLOGY TO OPTIMIZE WINTER WHEAT RESPONSE TO GLOBAL CLIMATE CHANGE," Conference on Applied Statistics in Agriculture. https://doi.org/10.4148/2475-7772.1208

This is brought to you for free and open access by the Conferences at New Prairie Press. It has been accepted for inclusion in Conference on Applied Statistics in Agriculture by an authorized administrator of New Prairie Press. For more information, please contact cads@k-state.edu. 
Author Information

P. Dhungana, K. M. Eskridge, A. Weiss, and P. S. Baenziger

This is available at New Prairie Press: https://newprairiepress.org/agstatconference/2002/proceedings/14 


\title{
SIMULATION AND RESPONSE SURFACE METHODOLOGY TO OPTIMIZE WINTER WHEAT RESPONSE TO GLOBAL CLIMATE CHANGE
}

\author{
P. Dhungana, K. M. Eskridge \\ Department of Biometry, University of Nebraska- Lincoln, Lincoln, NE,
}

A. Weiss

School of Natural Resource Sciences, University of Nebraska- Lincoln, Lincoln, NE,

and

P. S. Baenziger

Department of Agronomy and Horticulture, University of Nebraska- Lincoln, Lincoln, NE

\begin{abstract}
Future climate changes can have a major impact on crop production. But, whatever the climatic changes, crop production can be adapted to climate change by implementing alternative management practices and developing new genotypes that will take full advantage of the future climatic conditions. Since the classical agronomic research approach is not possible in identifying these new agronomic technologies for the future climatic conditions, we used response surface methodology (RSM) in connection with the CERES-Wheat crop model and the HADCM2 climate simulation model to identify optimal configuration of plant traits and management practices that maximize yield of winter wheat under high $\mathrm{CO}_{2}$ environments. The simulations were conducted for three Nebraska locations (Havelock, Dickens and Alliance), which were considered representative of winter wheat growing areas in the central Great Plains. At all locations, the identified optimal winter wheat cultivar under high $\mathrm{CO}_{2}$ conditions had a larger number of tillers, larger kernel size, shorter days to flower, grew faster and had more kernels per square meter than the check variety under normal $\mathrm{CO}_{2}$ conditions, while the optimal planting dates were later and planting densities were lower than under normal conditions. We concluded that RSM used in conjunction with crop and climate simulation models was a useful approach to understanding the complex relationship between wheat genotypes, climate and management practices.

Keywords: Response surface methodology, steepest ascent, global climate change, CERESWheat model, high $\mathrm{CO}_{2}$ conditions.
\end{abstract}

\section{Introduction}

Though a debate about scientific prediction of future climatic change scenario has not been resolved yet, there is common consensus about rising global temperature (termed as 'Global Warming') and changes in concentration of green house gases in the atmosphere. The atmospheric concentration of $\mathrm{CO}_{2}$ has increased from about $280 \mu \mathrm{mol} / \mathrm{mol}$ before the industrial revolution to about $358 \mu \mathrm{mol} / \mathrm{mol}$ in 1994 (IPCC, 1995). Global surface temperatures have 
increased about $0.3-0.6^{\circ} \mathrm{C}$ since the late $19^{\text {th }}$ century (Jones et al., 1999). Also current climate models have predicted an increase of the earth surface's temperature from 1.5 to $4.5^{\circ} \mathrm{C}$ over next 100 years due to increased green house gases (Houghton et al., 1996). These models also have predicted that the atmospheric concentration of $\mathrm{CO}_{2}$ gas could double in the next 100 years.

The combined effect of increase in $\mathrm{CO}_{2}$ concentration and associated changes in temperature and precipitation pattern on crop production is difficult to evaluate. Changes in temperature and precipitation patterns during critical periods of crop development can have dramatic positive or negative impacts while increases in $\mathrm{CO}_{2}$ concentration can raise the rate of photosynthesis, promoting biomass accumulation, increasing plant growth and yield (Kimball 1983; Cure and Acock, 1986). Whatever the climatic changes, crop production can be adapted to climate change by implementing alternative management practices and developing new genotypes that will take full advantage of the future climatic conditions. However, these new agronomic technologies cannot be identified without understanding future climatic conditions that are likely to result. In addition, developing new cultivars for future climate conditions is not possible without having knowledge of crop characteristics or traits that will allow the crop to take full advantage of future climate. Evaluating the possible long-term impacts of future global climate change on agronomic technologies such as crop genetics and management can be useful in understanding what types of cultivars and management practices may be necessary under likely future climatic conditions.

In this type of work, it is generally not possible to conduct experiments under future environmental conditions, nor is it simple to approximate the cumulative changes in technologies over a long period of time. Identifying agronomic technologies that may be necessary under future global climatic conditions requires three components: (1) a method to generate or simulate future environmental and climatic conditions, (2) the ability to predict plant response under these future conditions and (3) an approach that approximates the decision process of identifying and selecting new agronomic technologies. Climate simulation models and crop growth and yield models have been used extensively to predict plant responses under future climatic conditions (Rosenweig et al., 1995; Acock and Acock, 1993; Kenny et al., 1993). However, no clear methodology has been proposed that simulates the long-term decision making process of identifying new agronomic technologies in conjunction with predicted plant responses under simulated future global climatic conditions.

The decision process of identifying new agronomic technology may be conceptualized as an optimization procedure. Loomis (1993) also has suggested that using optimization methods with mathematical models of crops may be helpful in examining ideotype questions. Response surface methodology (RSM) is an optimization approach commonly used in industrial process control and engineering where the goal is to find levels of input variables that optimize a particular response (Myers and Montgomery, 1995). RSM proceeds sequentially with a series of experiments to find the area near the optimal (maximum or minimum) response where a final experiment is then conducted to find the 'optimal' input combinations. RSM is most useful when a response depends on many factors and the objective is to find the levels of these factors that give an optimum response. Hence, RSM used in connection with crop and climate simulation models can be adapted to approximate the long-term decision process of identifying agronomic technology that may be necessary under future climatic conditions.

In this work, we used the CERES-Wheat model to simulate yield of a wheat crop as a 
function of climatic variables, genetic coefficients, soil characteristics and management practices (Tsuji et al., 1994). CERES-Wheat is designed to simulate daily growth and development of wheat plants and has been validated under a wide-range of conditions (Otter-Nacke et al., 1986). To simulate weather input of future climatic conditions, we used the LARS-WG V2.6 stochastic weather generator, to simulate the weather data (Racsko et al., 1991; Semenov et al., 1998; Semenov et al., 1999) based on a well-known climate model, the Hadley Center Global Climate Model (HADCM2)(Johns et al., 1997). The objectives of this research are to demonstrate how to use RSM with crop and climate models to search for an optimal configuration of plant traits and crop management practices that maximize winter wheat yield under future high $\mathrm{CO}_{2}$ environments

\section{Materials and Methods}

Based on the CERES-Wheat model and simulated weather data from HADCM2, RSM was used to identify the levels of the non-weather CERES-Wheat input variables $\left(X^{\prime} s\right)$ that maximized yield under two $\mathrm{CO}_{2}$ weather scenarios (Normal: $360 \mathrm{ppm}$; High $720 \mathrm{ppm}$ ) at three Nebraska locations. We used RSM in three steps. First, using the method of steepest ascent, we identified the region of the CERES-Wheat input variables that gave near maximum yield. Second, we ran a final set of CERES-Wheat simulations to more carefully estimate the surface in the area of the maximum yield and to estimate the optimal inputs $\left(X^{\prime} s\right)$. Finally, we evaluated the shape and orientation of the response surface to determine if the optimal $X^{\prime} s$ gave a maximum or saddle point, and to identify a further path of steepest ascent if needed.

CERES-Wheat simulates yield, growth and development of a wheat crop as a function of weather variables, genetic coefficients, soil characteristics and management practices (Tsuji et al., 1994). The model uses seven genetic coefficients related to anthesis date, maturity date, the number of grains per square meter, grain weight and the number of grains per spike. In addition, soil characteristics and management factors related to planting, fertilization and irrigation are also required as input variables. The model also simulates daily growth and development of plants considering daily minimum and maximum temperature, precipitation and solar radiation, however we did not use the growth and development variables in subsequent analyses.

Five genetic and one management factors were considered as input variables and all other factors were considered fixed in the optimization procedure. The five genetic factors used as variables were: P1D - the relative amount of development that is slowed when plants are grown in a photoperiod 1 hour shorter than the optimum (which is considered to be 20 hours); P5 - the relative grain filling duration based on thermal time (degree-days above a base temperature of $1^{\circ}$ C), where each unit increase above zero adds 20 degree days to an initial value of 430 degree days; G1 - the kernel number per unit weight of stem (less leaf blades and sheaths) plus spike at anthesis (1/g); G2 - the kernel filling rate under optimum conditions (md/dy); G3 - non-stressed dry weight of a single stem (excluding leaf blades and sheaths) and spike (grain ear) when elongation ceases $(\mathrm{g})$. One of the genetic factors was held constant: P1V, defined as "relative amount that development is slowed for each day of unfulfilled vernalization, assuming that 50 days of vernalization is sufficient for all cultivars" was fixed at six (6) to represent winter wheat.

Plant population density, defined as the number of plants per square meter, was used as a management input variable and was allowed to vary to find the optimal plant population that 
maximized yield. Sowing dates used with the normal $\mathrm{CO}_{2}$ condition were based on the current management practices at each site. The sowing dates used with the high $\mathrm{CO}_{2}$ scenarios were chosen to approximate the dates when the mean air temperature from the high $\mathrm{CO}_{2}$ scenarios was the same as the mean air temperature of current sowing dates (Table 1). Nitrogen was held constant at $50 \mathrm{~kg} \mathrm{ha}^{-1}$. No irrigation was assumed and the simulation was run assuming rain-fed production. The remaining management variables were held constant. It was assumed that no biotic stresses were present. Among abiotic stresses, temperature, soil water, soil nitrogen and $\mathrm{CO}_{2}$ concentration were considered. The ranges of the genetic factors were based on the lowest and highest values for the set of released winter wheat cultivars listed in DSSAT manuals (Table 2) ( Tsuji et al., 1994). The genetic factors were limited to these ranges since the precision of CERES-Wheat predictions beyond these ranges is unknown. The current data for soil characteristic for each of three locations were also used (Won, 2001 ).

Two different climatic scenarios were used in this study: normal $\mathrm{CO}_{2}(360 \mu \mathrm{mol} / \mathrm{mol})$ with the current climatic conditions and high $\mathrm{CO}_{2}(720 \mu \mathrm{mol} / \mathrm{mol})$ with future climatic conditions after 100 years based on the Hadley Center Global Climate Model (HADCM2 ) (Johns et al., 1997). The stochastic weather generator, LARS-WG V2.6 was used to simulate the weather data (Racsko et. al, 1991; Semenov et. al, 1998; Semenov et. al 1999). It required three input files: 1) latitude, longitude and elevation, 2) observed weather data consisting of daily values for at least one year (we used 15 years in this study) and 3) weather scenario files created by using the relationship between 100 years of simulated historical weather data from Vegetation/Ecosystem Modeling and Analyzing Project (VEMAP) phase 2 (Kittel et al., 1997) grided record (1895-1993) and 100 years of simulated weather data for high $\mathrm{CO}_{2}$ conditions using the UKMO Hadley center HADCM2 global climate model (Johns et al., 1997). One hundred normal and high $\mathrm{CO}_{2}$ "years" were generated for three locations in Nebraska: Havelock (sub-humid climate; $40^{\circ} 51^{\prime} \mathrm{N}$ Lat, 96 $36^{\circ}$ ' W Long., $347 \mathrm{~m}$ elev.), Alliance (semi-arid climate; $42^{\circ} 30^{\prime} \mathrm{N}$ Lat, $102^{\circ} 55^{\prime} \mathrm{W}$ Long., $1213 \mathrm{~m} \mathrm{elev.)}$ and Dickens (transition between sub-humid and semi-arid; $40^{\circ} 57^{\prime} \mathrm{N}$ Lat, $100^{\circ} 58^{\prime}$ W Long., $945 \mathrm{~m}$ elev.). These three locations are reasonably representative of the major portion of the winter wheat growing areas in the Central Great Plains of the US (Peterson, 1992).

We ran the CERES-Wheat model using the normal $\mathrm{CO}_{2}$ concentration with current hundred years' weather and a doubled $\mathrm{CO}_{2}$ concentration of $720 \mu \mathrm{mol} / \mathrm{mol}$ with the future hundred years' weather. Response Surface Methodology (RSM) was used to identify the levels of the six CERES-Wheat input variables to maximize grain yield at the three sites under normal and high $\mathrm{CO}_{2}$ conditions. A second-order design and model were then used to estimate the response surface near the maximum and finally, canonical analysis was used to characterize the nature of the surface around the maximum.

\subsection{Finding the area of the maximum: the method of steepest ascent.}

We used this method to sequentially find an area near the maximum yield using the following steps. The method of steepest ascent allows us to find the values of the six input variables (P1D, P5, G1, G2, G3 and planting density) in the area near the maximum yield.

$\mathrm{I}$ : Starting values and ranges of experimental factors. Initial starting points for the six input variables were established by using the genetic coefficients for a winter wheat variety 
'Karl-92' (Xue, 2000) and using the planting density commonly used by farmers at each location (Table 3). 'Karl-92' was chosen since it is a relatively modern cultivar adapted to the central Great Plains. The low and high values were chosen so that they were sufficiently different to ensure a primarily linear response but not large to induce curvature effects.

II: First order experiments. Six input variables were considered in this study and use of a full factorial design with 2 levels for each input factor would require an excessive number of simulations since it would be necessary to run $2^{6}=64$ design points with 100 years of simulations for each design point. Since the path of steepest ascent is computed from a planar-type of surface obtained by fitting a first-order main effects model excluding interactions, it is only necessary to use a portion of the $2^{6}$ design points. In our study, Plackett-Burman design (PBD) was used because it allows one to evaluate up to $n-1$ factors in $n$ design points when $n$ is divisible by four (Lin And Draper, 1992). The first six columns from a $n=12$ PBD were considered to identify the 12 design points for each first-order experiment conducted when using the steepest ascent procedure (Table 4).

III: First-order model and the path of steepest ascent. For a given first-order experiment, mean yields over 100 years of simulations were obtained for each of the design points. Using the mean yields as the values of the dependent variable, the following first-order model was fitted

$$
\hat{\mathrm{y}}=b_{0}+\Sigma b_{i} X_{i} ; i=1,2, \ldots 6
$$

where the slope coefficients $\left(b_{i}\right)$ were estimated using least-squares and the $X_{i}$ were in coded form with $X_{i}=+1$ for the high level of the factor and $X_{i}=-1$ for the low level. To identify the path of steepest ascent, the largest $\left|b_{\mathrm{i}}\right|$ was identified and the ratio $b_{\mathrm{j}} / \max \left|b_{\mathrm{i}}\right|, i \neq j=1, \ldots 6$ was obtained for each variable. Step sizes of $\Delta X_{i}=0.4$ were used and values of $X_{j}=$ ratio* $\Delta X_{i}+$ starting value, for each variable were identified as points on the path of steepest ascent. The points on the path were translated to the original scales for the six CERES-Wheat input variables and the crop model was simulated for each of the points on the path. Simulations were run for points along the path until either the mean of the simulated yield was substantially less than the predictions from the first-order model or when the mean yield decreased substantially. In addition to these cases, we stopped making runs on the path if at least one of the values for genetic factors was beyond the predefined ranges in Table 2. In either case, we stopped, returned to step II, another PBD was set up at that point and continued. If any of the genetic input was out of range, the values for those inputs were fixed at predefined and the subsequent first-order experiments were conducted varying the remaining inputs.

IV: Terminating steepest ascent. The steps II to III were repeated until either (1) all the least squares slope coefficients $\left(b_{i}\right.$ 's) were small or (2) only a small increase in yield was obtained by additional runs on the path, or (3) the harvest index achieved a value of 0.5 , the highest achievable value (Slafer et al., 1993).

\subsection{Simulation experiments near the area of the maximum: Second order design and model}

Assuming the method of steepest ascent identifies the values of the CERES-Wheat input variables near the maximum yield, an appropriate experimental design and estimated response 
surface are then needed to precisely estimate the input values that maximize yield. A central composite design (CCD) was used to identify the design points for the final set of simulation runs (Myers and Montgomery, 1995). Using the means of the simulated yields for the points from the CCD, the following second order model was fitted

$$
y_{i j}=b_{0}+\Sigma b_{i} X_{i}+\Sigma b_{i i} X_{i}^{2}+\Sigma \Sigma b_{i j} X_{i} X_{j} \quad i, j=1, \ldots, k
$$

where $b^{\prime} s$ are the linear $\left(b_{i}\right)$, quadratic $\left(b_{i i}\right)$ and cross-product $\left(b_{i j}\right)$ regression coefficients estimated using least-squares and $k$ is the number of input variables in the final experiment. In matrix notation, the model is written as

$$
y=b_{o}+X^{\prime} b+X^{\prime} \boldsymbol{B} X
$$

where $X^{\top}=$ row vector of input values $=\left[\begin{array}{ll}X_{1} & X_{2} \ldots . . X_{k}\end{array}\right] ; b^{`}=\left[b_{1} b_{2} \ldots \ldots . b_{k}\right]$ a row vector of linear slope coefficients, $\boldsymbol{B}=$ a matrix of quadratic and cross-product regression coefficients. These coefficients $(b ' s)$ were estimated using least-squares and the fit of the model was evaluated using $R^{2}$. The significance of each model term (linear, quadratic and cross product) was tested using residual error variance.

\subsection{Identifying input levels that maximized yield and evaluation of the surface}

The values of the experimental variables that maximized yield were determined by differentiating the second order model and equating the derivative to zero and solving as follows: $\delta y / \delta X=b+2 \mathbf{B} x=0$ which implies that $X_{0}=-1 / 2 * \mathbf{B}^{-1 *} b$ where $\mathrm{X}_{0}$ is the stationary point and the value of yield at the stationary point is $y_{0}=b_{0}+1 / 2 * X_{0}{ }^{-} * b$, where $\boldsymbol{B}^{-1}$ is the inverse of $\boldsymbol{B}$.

To evaluate the surface in the area of the optimum, the second order model was transformed to the canonical model,

$$
y=y_{0}+\Sigma \lambda_{i} W_{i}^{2}
$$

where the $\lambda_{i}, \mathrm{~s}$ are eigenvalues of $\mathbf{B}$ and the $W_{i}$ 's are the canonical variables (Myers \& Montgomery, 1995). The $W_{i}$ 's are the variables for transformed axes that identify the orientation of the second-order response surface. The canonical model is useful (1) for determining if the stationary point is a maximum, a minimum or a saddle point and (2) to evaluate the change in yield as one moves from the stationary point to the nearby points. The $\lambda_{i}$ 's identify the nature of the stationary point. If the $\lambda_{i}{ }^{\prime} s$ are all negative then any movement away from the stationary point will reduce $y$ and so $X_{0}$ is a maximum. Similarly, if all the $\lambda_{i}{ }^{\prime} s$ are positive, $X_{0}$ is a minimum and when the $\lambda_{i}$ 's are mixed signs then $X_{0}$ is a saddle point.

The estimated surface was characterized on the basis of the following criterion:

Case I: If the stationary point determined by the model was inside the experimental region and all $\lambda_{i}, s$ were less than zero, the stationary point, $X_{0}$ is the point of maximum yield response. Case II: If the stationary point determined by the model was outside the range of the design points from the second-order design, and some $\lambda_{i}$ 's were less than zero and some were greater than zero, the stationary point, $X_{0}$ was a saddle point. The saddle point can be evaluated by the values of the $-\lambda_{i}$ and $+\lambda_{i}$. When the response surface was a saddle, a ridge of steepest ascent was estimated and further simulation runs on these ridges were conducted until there was only a slight increase in yield and this final point was considered maximum.

\section{Results and Discussion}


The optimum values for the genetic factors suggested that the optimal cultivar for the future high $\mathrm{CO}_{2}$ conditions should have less photoperiod sensitivity (P1D), long grain filling duration (P5) and high kernel filling rate (G2) (Tables 6). This result agreed with Hall and Allen (1993) who found that cultivars for future climatic conditions should extend the grain filling period, shorten the duration of vegetative growth (which would also improve harvest index) and be adapted to appropriate photoperiod.

Agronomic results from this study are presented for three cases for each location. Case 1 is the current variety, Karl-92, under normal $\mathrm{CO}_{2}$ conditions. Case 2 is also for Karl-92 but under high $\mathrm{CO}_{2}$ conditions (future climatic scenario) and case 3 is the new cultivars determined by RSM under high $\mathrm{CO}_{2}$ conditions (Table 5). In all three cases, the increasing trends of yield were observed for semi-arid (Alliance, NE), transitional (Dickens, NE) to sub humid (Havelock, NE) environments (Tables 5). Overall, the results indicated that the 'optimal' cultivar under high $\mathrm{CO}_{2}$ conditions produced $65 \%$ to $150 \%$ more yield than 'Karl 92' under normal $\mathrm{CO}_{2}$ conditions (Figures 1-3). This study also showed that the optimal variety had 20 to $35 \%$ more kernel weight and 35 to $90 \%$ more kernels $\mathrm{m}^{-2}$ than 'Karl 92' under normal $\mathrm{CO}_{2}$ conditions, while kernels per spike was relatively unchanged (Figures 1-3). In addition, the optimal planting density under high $\mathrm{CO}_{2}$ conditions was from $1 \%$ to $19 \%$ less than the currently used planting densities. More kernels $\mathrm{m}^{-2}$ with little change in kernels per spike and reduced planting density indicated that the number of tillers per plant was higher under high $\mathrm{CO}_{2}$ condition for both 'Karl 92' and the optimal cultivar. At all locations, the optimal varieties under high $\mathrm{CO}_{2}$ had shorter days to flower, grew faster, and had more kernels $\mathrm{m}^{-2}$ than 'Karl 92' under normal $\mathrm{CO}_{2}$ conditions, and yield was improved under high $\mathrm{CO}_{2}$ conditions by sowing three weeks later than normally practiced (Table 5).

Identifying appropriate agronomic technologies that may be appropriate for future climatic conditions is difficult since (1) it is not possible to conduct field experiments under future climatic conditions and (2) because chamber experiments that approximate future climate conditions are by necessity quite small, may not accurately represent field conditions, and can only be used to evaluate a very few cultivars and/or agronomic practices at a time. Using response surface methodology in conjunction with crop and weather simulation models may allow researchers to identify combinations of plant traits and management practices that indicate needed changes in managed field crop systems as a result of future climate scenarios. The approach can be useful (1) in understanding the complex relationships among crop genotypes, climate and management, (2) for comparing various crop and weather models regarding the theoretical optima and (3) to agricultural scientists and policy makers who are assessing how climate change may impact the agriculture and society.

The method of steepest ascent also has several limitations. The method will identify the area near the global optimum if the response surface is quadratic in the $X^{\prime} s$. In situations where the surface is more complicated than a quadratic, the method of steepest ascent may identify an area near a local optimum. One way to check if the area contains a global optimum is to evaluate points away from identified area to ensure they are sub-optimal. Another approach is to begin a new steepest ascent session with different starting points and a global area of the optimum would be indicated if a similar area is identified as before. In this application, we considered points outside the final design and different starting values which both indicated that we had identified the area that contained the global maximum. Also, the method of steepest ascent can also be 
quite time consuming since the approach is sequential in nature.

\section{Summary}

In this study, application of this methodology to winter wheat in the US Great Plains tended to support the hypothesis that under high $\mathrm{CO}_{2}$ - high temperature conditions, translocating more energy to the tillering and grain size at the expense of other traits of the plant could result in dramatically higher yields without substantially changing crop management practices except planting dates. Although this type of information can be only considered preliminary since it is strongly based on the assumptions that the weather and plant simulation models produce valid predictions, it can be a valuable tool in assessing how climate changes may impact winter wheat production in the US Great Plains in the years to come. Using response surface methodology in conjunction with crop and weather simulation models may allow researchers to identify combinations of plant traits and management practices that indicate needed changes in managed field crop systems as a result of future climate scenarios. The approach can be useful (1) in understanding the complex relationships among crop genotypes, climate and management, (2) for comparing various crop and weather models regarding the theoretical optima and (3) to agricultural scientists and policy makers who are assessing how climate change may impact the agriculture and society.

\section{Acknowledgements}

We thank Daryl Travnicek for his help in writing SAS program to manage output produced by CERES-Wheat model. We also thank Jaepil Won for providing technical support to run CERES-Wheat. Comments from anonymous referee are greatly acknowledged

\section{References}

Acock, B. and Acock, M.C. 1993. Modelling approaches for predicting crop ecosystem responses to climate change. In: International Crop Science I.D.R. Buxlon et al. (eds.) . Crop Science Society of America, Madison, W,I, PP 299-306.

Cure, J.D. and Acock, B. 1986.Crop response to carbon dioxide doubling:a literature survey. Agr. and forest meteor.38:127-145.

Hall, A.E. and Allen, L.H. Jr. 1993. Designing cultivars for the climatic condition of the next century. In: International Crop Science I. Dr. Boxton, R. Shibles, R.A. Forsberg, B.L. Blad, K.H. Assaj, G.M.Paulsen and R.F. Wilson (eds.). Crop Science Society of America. Madison, Wisconsin, PP. 291-297.

Houghton, J. T., Meira Filho, L.G., Callander, B.A., Harris, N., Kattenburg, A. And Maskell, K. 1996. IPCC Climate Change Assessment 1995: The Science of Climate Change, Cambridge University Press, Cambridge, UK 572 pp. 
IPCC 1995. Climate change 1995: The science of climate change. Contribution of working group I to the second assessment report of the Intergovernmental Panel on Climate Change. Edited by J.T. Houghton, L.G.Meira Filho, B.A. Callander, N.Harris, A. Kattenberg and K. Maskell.

Johns, T. C., R. E. Carnell, J. F. Crossley, J. M. Gregory, J. F. B. Mitchell,C. A. Senior, F. B. Tett and R. A. Wood, 1997. The Second Hadley Centre coupled oceanatmosphere GCM: Model description, spinup and validation, Climate Dynamics, 13, 103134.

Jones, P.D., Parker, D.E., Osborn, T.J., and Britta, K.R.. 1999. Global and hemispheric temperature anomalies-land and marine instrumental record. In: Trends: a Compendium of Data on Global Change. Carbon Dioxide Information Analysis Center, Oak Ridge National Laboratory Oak Ridge, Tennessee.

Kenny, G.J., Harrison, P.A., Olesen, J.E. and Parry, M.J. 1993. The effects of climate change on land suitability of grain maize, winter wheat and cauliflower in Europe. Eur. J. of Agronomy 2: 325-338.

Kimball, B.A. 1983.Carbon dioxide and agricultural yield:An assemblage and analysis of 430 prior observations. Agron. J. 75:779-788.

Kittle, T.G.F., Royle, J.A., Daly, C., Rosenbloom, N.A., Gibson, W.P., Fisher, H.H., Schimel, D.S., Berliner, L.M., and VEMAP2 Participants.1997. A gridded historical (1895-1993) bioclimate dataset for the conterminous United States. In: Proceedings of the $10^{\text {th }}$ Conference on Applied Climatology, 20-24 October 1997, Reno, NV. American Meteorological Society, Boston.

Lin, D.K.J. and Draper, N.R. 1992. Projection Properties of Placket Burman Design. Technometrics, vol 34, no. 47.

Loomis, R.S. 1993. optimization theory and crop improvement. International Crop Science I. Crop Science Society of America, PP.583-588.

Myers, R.H. and Montgomery, D.C. 1995. Response surface methodology: process and product optimization using designed experiment. A wiley interscience publication.

Otter-Nacke, S., Godwin, D.C. and Ritchie, J.T. 1986. Testing and validating the CERES-Wheat model in diverse environments. Publ. ISC.20244.Johnspace cir, Houston TX.

Peterson, C.J. 1992. Similarities among test sites based on cultivars performance in the hard red winter wheat region. Crop Sci. 32: 907-912.

Racsko, P., Szeidi, L. and Semenov, M. 1991.A serial approach to local stochastic weather models. Ecological modeling, 57:27-41.

Rosenzweig, C., Ritchie, J.T., Jones, J.W., Tsuji, G. Y. and Hildebrand, P. 1995. Climate change and agriculture: analysis of potential international impacts. ASA Spec. publ.59. ASA Madison. WI.

Semenov, M. A., Brooks, R. J., Barrow, E.M. and Richardson C.W. 1998.Comparison of the WGEN and LARS-WG stochastic weather generator in diverse climate. Climate research 10:95-107.

Semenov, M. A. and Brooks, R. J . 1999. Spatial interpolation of the LARSWG stochastic weather generator in Great Britain. Climate research 11:137-148. 
Slafer A. G., Jose L. A., Richard A. R. 1999. Physiological traits that increase the yield potential of wheat. In Wheat: Ecology and physiology of yield determination.Edited by Emilio H. S., Gustavo A. S. 379-415.

Tsuji, G.Y. Uehara, G. and Balas, S.(eds.) 1994. DSSAT V3. University of Hawaii, Honolulu.

Won, J. 2001. Assessing winter wheat response to global climate change. Thesis (MS), University of Nebraska Lincoln.

Xue,Q. 2000.Phenology and gas exchange in winter wheat. Thesis (Phd), University of Nebraska Lincoln. 
Table 1. Sowing date used for current and future climatic scenarios in three Nebraska locations

\begin{tabular}{llll}
\hline Scenario & Alliance & Dickens & Havelock \\
\hline $\begin{array}{l}\text { Current } \\
\left(\mathrm{CO}_{2}=360 \mu \mathrm{mol} \mathrm{mol}^{-1}\right)\end{array}$ & September 8 & September 18 & September 26 \\
$\begin{array}{l}\text { Future } \\
\left(\mathrm{CO}_{2}=720 \mu \mathrm{mol} \mathrm{mol}^{-1}\right)\end{array}$ & September29 & October 9 & October 17 \\
\hline
\end{tabular}

Table 2. Predefined ranges for the value of Genetic Input variables used in the CERES-Wheat model

\begin{tabular}{lll}
\hline Input & Lower limit & Upper limit \\
\hline P1D & 1.0 & 4.7 \\
P5 & 1.0 & 5.0 \\
G1 & 1.1 & 5.5 \\
G2 & 1.3 & 6.8 \\
G3 & 1.0 & 4.4 \\
\hline
\end{tabular}

$\mathrm{P} 1 \mathrm{D}=$ Photoperiod sensitivity; $\mathrm{P} 5=$ grain filling duration, $\mathrm{Gl}=$ related to kernel number per Spike; $\mathrm{G} 2=$ Kernel filling rate; $\mathrm{G} 3=$ related to kernel weight

Table 3. Initial values and ranges for CERES-Wheat input variables used in the steepest ascent procedure to identify an area near maximum yield:

\begin{tabular}{lccllll}
\hline Location & P1D & P5 & G1 & G2 & G3 & Plants/M \\
\hline Alliance & 2.9 & 1.5 & 4.0 & 2.1 & 2.0 & 160 \\
Dickens & 2.9 & 1.5 & 4.0 & 2.1 & 2.0 & 200 \\
Havelock & 2.9 & 1.5 & 4.0 & 2.1 & 2.0 & 260 \\
Range & \pm 0.2 & \pm 0.2 & \pm 0.2 & \pm 0.2 & \pm 0.2 & \pm 10 \\
\hline
\end{tabular}

P1D = Photoperiod sensitivity; P5=grain filling duration, G1= related to kernel number per Spike; $\mathrm{G} 2=$ Kernel filling rate; $\mathrm{G} 3=$ related to kernel weight 
Table 4. Design points for initial first-order experiment at Alliance, NE for CERES-Wheat input variables used in the steepest ascent procedure to identify an area near maximum yield

\begin{tabular}{lllllll}
\hline $\begin{array}{l}\text { Design } \\
\text { point }\end{array}$ & P1D & P5 & G1 & G2 & G3 & Plants/M \\
\hline 1 & 3.1 & 1.3 & 4.2 & 1.9 & 1.8 & 150 \\
2 & 3.1 & 1.7 & 3.8 & 2.3 & 1.8 & 150 \\
3 & 2.7 & 1.7 & 4.2 & 1.9 & 2.2 & 150 \\
4 & 3.1 & 1.3 & 4.2 & 2.3 & 1.8 & 170 \\
5 & 3.1 & 1.7 & 3.8 & 2.3 & 2.2 & 150 \\
6 & 3.1 & 1.7 & 4.2 & 1.9 & 2.2 & 170 \\
7 & 2.7 & 1.7 & 4.2 & 2.3 & 1.8 & 170 \\
8 & 2.7 & 1.3 & 4.2 & 2.3 & 2.2 & 150 \\
9 & 2.7 & 1.3 & 3.8 & 2.3 & 2.2 & 170 \\
10 & 3.1 & 1.3 & 3.8 & 1.9 & 2.2 & 170 \\
11 & 2.7 & 1.7 & 3.8 & 1.9 & 1.8 & 170 \\
12 & 2.7 & 1.3 & 3.8 & 1.9 & 1.8 & 150 \\
\hline
\end{tabular}

$\mathrm{P} 1 \mathrm{D}=$ Photoperiod sensitivity; $\mathrm{P} 5=$ grain filling duration, $\mathrm{G} 1=$ related to kernel number per Spike; $\mathrm{G} 2=$ Kernel filling rate; $\mathrm{G} 3=$ related to kernel weight 
Table 5. Wheat Plant and Required Management for maximum yield at Lincoln, Dickens and Alliance, $\mathrm{NE}$ under high $\mathrm{CO}_{2}$ and current climatic conditions ( Kar192= 'Karl 92'; New=' optimal variety'; 360= normal $\mathrm{CO}_{2}$ conditions' $; 720={ }^{\prime} \mathrm{high}^{\mathrm{CO}} \mathrm{C}_{2}$ conditions')

\begin{tabular}{|c|c|c|c|c|c|c|c|c|c|}
\hline & \multicolumn{3}{|c|}{ Havelock } & \multicolumn{3}{|c|}{ Dickens } & \multicolumn{3}{|c|}{ Alliance } \\
\hline & $\begin{array}{l}\text { Karl92- } \\
360\end{array}$ & $\begin{array}{l}\text { Karl92- } \\
720\end{array}$ & $\begin{array}{l}\text { New- } \\
720 \\
\end{array}$ & $\begin{array}{l}\text { Karl92- } \\
360\end{array}$ & $\begin{array}{l}\text { Karl92- } \\
720 \\
\end{array}$ & $\begin{array}{l}\text { New- } \\
720 \\
\end{array}$ & $\begin{array}{l}\text { Karl92- } \\
360 \\
\end{array}$ & $\begin{array}{l}\text { Karl92- } \\
720 \\
\end{array}$ & $\begin{array}{l}\text { New- } \\
720 \\
\end{array}$ \\
\hline Planting Date & $\begin{array}{c}\text { September } \\
26\end{array}$ & $\begin{array}{c}\text { October } \\
17\end{array}$ & $\begin{array}{c}\text { October } \\
17\end{array}$ & $\begin{array}{c}\text { September } \\
18\end{array}$ & $\begin{array}{c}\text { October } \\
09\end{array}$ & $\begin{array}{l}\text { October } \\
09\end{array}$ & $\begin{array}{c}\text { September } \\
08\end{array}$ & $\begin{array}{c}\text { September } \\
29\end{array}$ & $\begin{array}{c}\text { September } \\
29\end{array}$ \\
\hline Plant Population & $260 / \mathrm{m} 2$ & $260 / \mathrm{m} 2$ & $238 / \mathrm{m} 2$ & $200 / \mathrm{m} 2$ & $200 / \mathrm{m} 2$ & $198 / \mathrm{m} 2$ & $160 / \mathrm{m} 2$ & $160 / \mathrm{m} 2$ & $132 / \mathrm{m} 2$ \\
\hline $\begin{array}{l}\text { Flowering } \\
\text { Date(DOY) }\end{array}$ & $\begin{array}{c}146 \\
\text { (May 26) }\end{array}$ & $\begin{array}{c}138 \\
\text { (May 18) }\end{array}$ & $\begin{array}{c}139 \\
\text { (May 19) }\end{array}$ & $\begin{array}{c}152 \\
\text { (June i) }\end{array}$ & $\begin{array}{c}141 \\
(\text { May 21) }\end{array}$ & $\begin{array}{c}138 \\
\text { (May 18) }\end{array}$ & $\begin{array}{c}156 \\
\text { (June 05) }\end{array}$ & $\begin{array}{c}143 \\
\text { (May 23) }\end{array}$ & $\begin{array}{c}133 \\
\text { (May 13) }\end{array}$ \\
\hline $\begin{array}{l}\text { Physiological } \\
\text { Maturity(DOY) }\end{array}$ & $\begin{array}{c}176 \\
\text { (June 25) }\end{array}$ & $\begin{array}{c}168 \\
\text { (June 17) }\end{array}$ & $\begin{array}{c}172 \\
\text { (June 21) }\end{array}$ & $\begin{array}{c}185 \\
\text { (July 4) }\end{array}$ & $\begin{array}{c}172 \\
\text { (June 21) }\end{array}$ & $\begin{array}{c}170 \\
\text { (June 19) }\end{array}$ & $\begin{array}{c}188 \\
\text { (July 07) }\end{array}$ & $\begin{array}{c}175 \\
\text { (June 24) }\end{array}$ & $\begin{array}{c}168 \\
(\text { Jun 17) }\end{array}$ \\
\hline Grain Yield $(\mathrm{Kg} / \mathrm{Ha})$ & 3371 & 3367 & 5805 & 2868 & 3104 & 5106 & 1990 & 2608 & 5086 \\
\hline Weight/ Grain(mg) & 30.4 & 30.1 & 37.2 & 30.1 & 29.3 & 37.78 & 28.3 & 28.9 & 38.1 \\
\hline Grain/m2 & 11077 & 11175 & 15650 & 9453 & 10563 & 13494 & 6981 & 8955 & 13288 \\
\hline Grain/spike & 11 & 9 & 15 & 9 & 8 & 9 & 8 & 7 & 9 \\
\hline $\begin{array}{l}\text { Leaf Area Index } \\
(\mathrm{m} 2 / \mathrm{m} 2)\end{array}$ & 3.37 & 3.18 & 2.96 & 2.48 & 2.73 & 2.64 & 2.34 & 2.89 & 2.64 \\
\hline $\begin{array}{l}\text { Biomass at } \\
\text { Anthesis }(\mathrm{kg} / \mathrm{ha})\end{array}$ & 6656 & 6124 & 6563 & 5145 & 5289 & 5280 & 4919 & 5171 & 5321 \\
\hline $\begin{array}{l}\text { Biomass at } \\
\text { Harvest }(\mathrm{kg} / \mathrm{ha})\end{array}$ & 10267 & 10182 & 11567 & 8334 & 9334 & 9983 & 6881 & 8333 & 9863 \\
\hline $\begin{array}{l}\text { Stalk at } \\
\text { Harvest }(\mathrm{kg} / \mathrm{ha})\end{array}$ & 6897 & 6815 & 5762 & 5467 & 6229 & 4877 & 4890 & 5725 & 4776 \\
\hline $\begin{array}{l}\text { Harvesting } \\
\text { Index }(\mathrm{kg} / \mathrm{kg})\end{array}$ & 0.33 & 0.33 & 0.5 & 0.34 & 0.33 & 0.5 & 0.28 & 0.31 & 0.50 \\
\hline
\end{tabular}


Table 6. genetic coefficient values for existing variety, Karl-92 and new varieties for each location ( Kar192= ' Karl 92'; New=' optimal variety'; 360= normal $\mathrm{CO}_{2}$ conditions' ;720= ' high $\mathrm{CO}_{2}$ conditions')

\begin{tabular}{crrrr}
\hline \multirow{2}{*}{ Factors } & Kar192 & Alliance & Dickens & \multicolumn{2}{c}{ Havelock } \\
\cline { 2 - 5 } & New_720 & New_720 & New_720 \\
\hline P1V & 6 & 6 & 6 & 6 \\
P1D & 2.9 & 1 & 2.3 & 1.9 \\
P5 & 1.5 & 2 & 1.6 & 4.7 \\
G1 & 4 & 5.5 & 5.2 & 5.5 \\
G2 & 2.1 & 4.8 & 3.5 & 6 \\
G3 & 2 & 2 & 2 & 2 \\
\hline
\end{tabular}

$\mathrm{P} 1 \mathrm{D}=$ Photoperiod sensitivity; $\mathrm{P} 5=$ grain filling duration, $\mathrm{Gl}$ = related to kernel number per Spike;

$\mathrm{G} 2=$ Kernel filling rate; $\mathrm{G} 3=$ related to kernel weight

Figure 1. Grain and biomass components( Grn_yld=' grain yield'; Grn_wt=' weight per grain'; Grn_sqm= ' grains per square meter'; Grn_ear=' grains per spike'; Bm_anth= ' biomass at anthesis'; Bm_hrv= 'biomass at harvest' ; Stalk_hrv= 'stalk at harvest'; Lai=' leaf area index') as proportion of Karl 92 under normal conditions at Alliance, NE for four cases( Karl92= ' Karl 92'; New=' optimal variety'; $360=$ normal $\mathrm{CO}_{2}$ conditions' ; $720=$ ' high $\mathrm{CO}_{2}$ conditions')
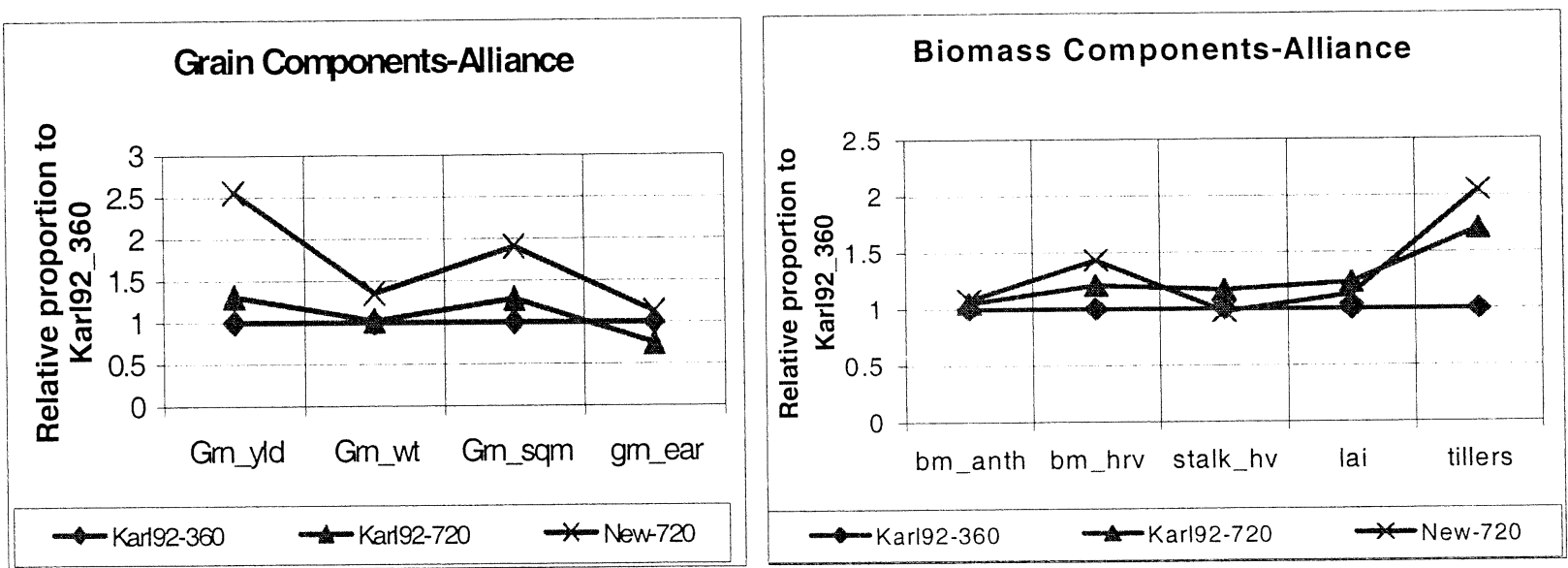
Figure 2. Grain and biomass components( Grn_yld=' grain yield'; Grn_wt=' weight per grain'; Grn_sqm= ' grains per square meter'; Grn_ear=' grains per spike'; Bm_anth= ' biomass at anthesis'; Bm_hrv= 'biomass at harvest' ; Stalk_hrv= 'stalk at harvest'; Lai=' leaf area index') as proportion of Karl 92 under normal conditions at Dickens, NE for four cases( Karl92= ' Karl 92'; New=' optimal variety'; $360=$ normal $\mathrm{CO}_{2}$ conditions' $; 720=$ ' high $\mathrm{CO}_{2}$ conditions')
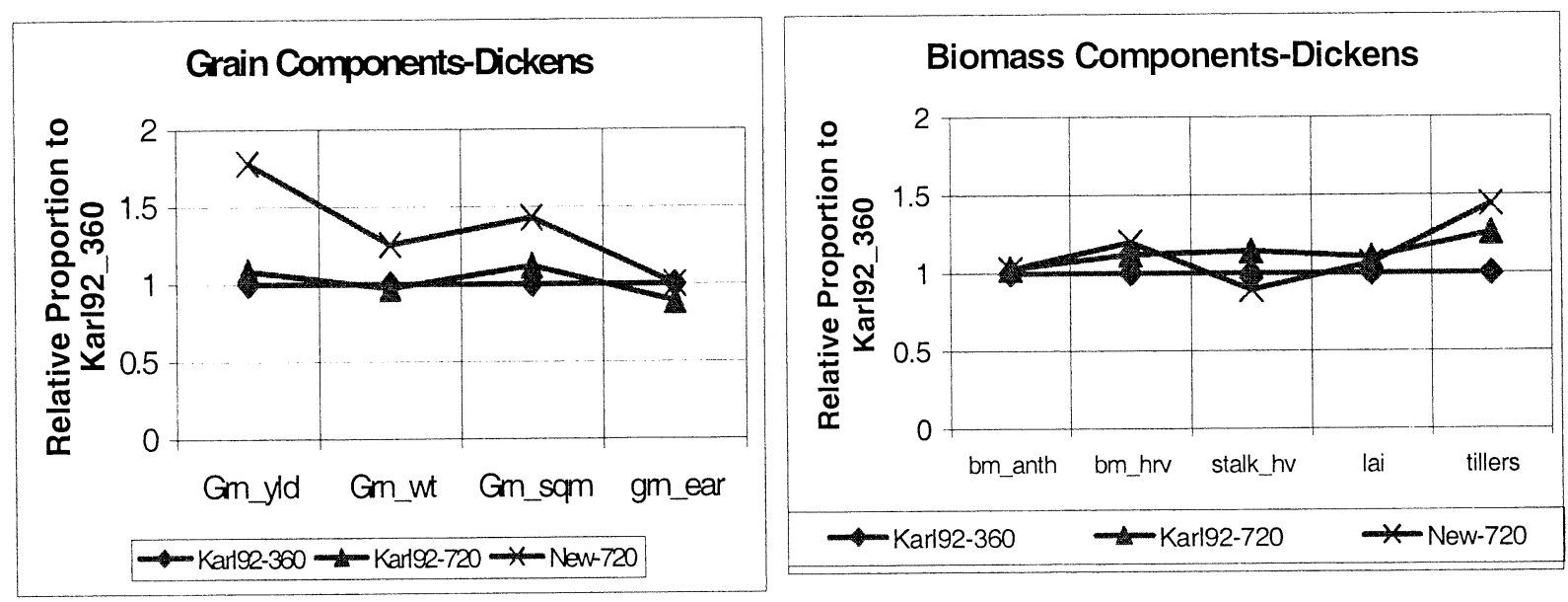

Figure 3. Grain and biomass components( Grn_yld=' grain yield'; Grn_wt=' weight per grain'; Grn_sqm= ' grains per square meter'; Grn_ear=' grains per spike'; Bm_anth= ' biomass at anthesis'; Bm_hrv= ' biomass at harvest' ; Stalk_hrv= 'stalk at harvest'; Lai=' leaf area index') as proportion of Karl 92 under normal conditions at Havelock, NE for four cases( Karl92= ' Karl 92'; New=' optimal variety'; $360=$ normal $\mathrm{CO}_{2}$ conditions' $; 720=$ ' high $\mathrm{CO}_{2}$ conditions')
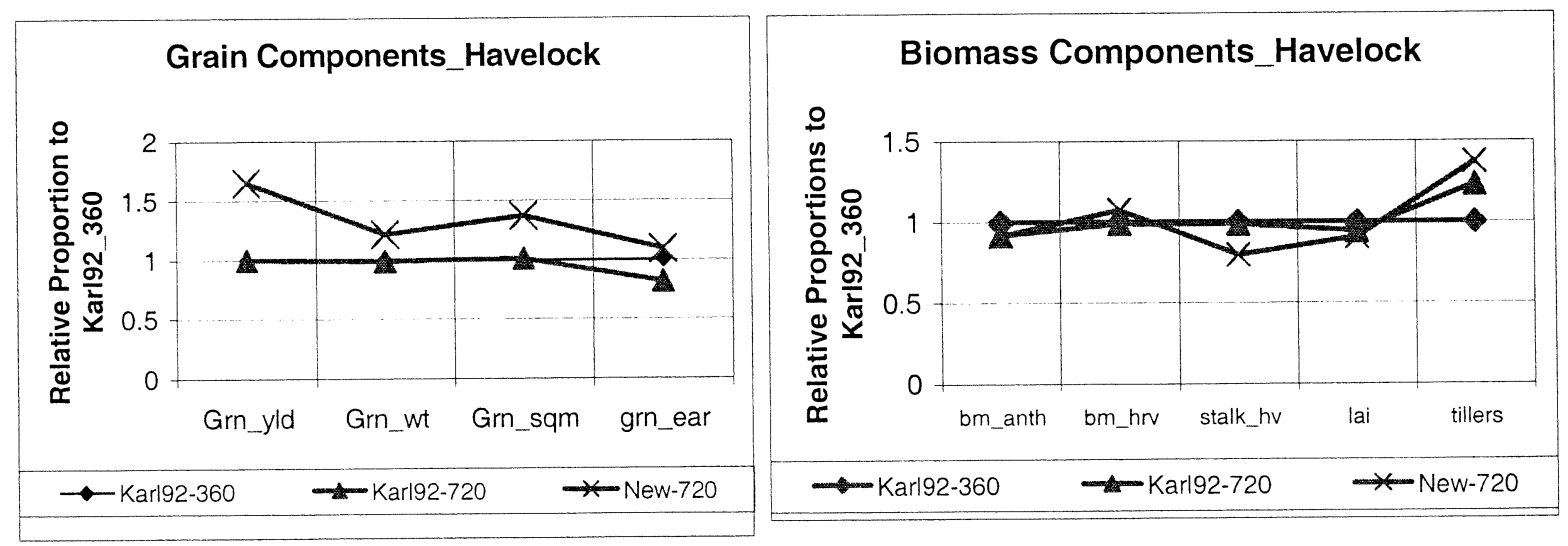